\title{
Ramon Margalef López
}

\author{
JOSEFINA CASTELLVÍ i PIULACHS
}

Gran Via de les Corts Catalanes 549, pral 2a., 08011 Barcelona, Catalunya, Spain.

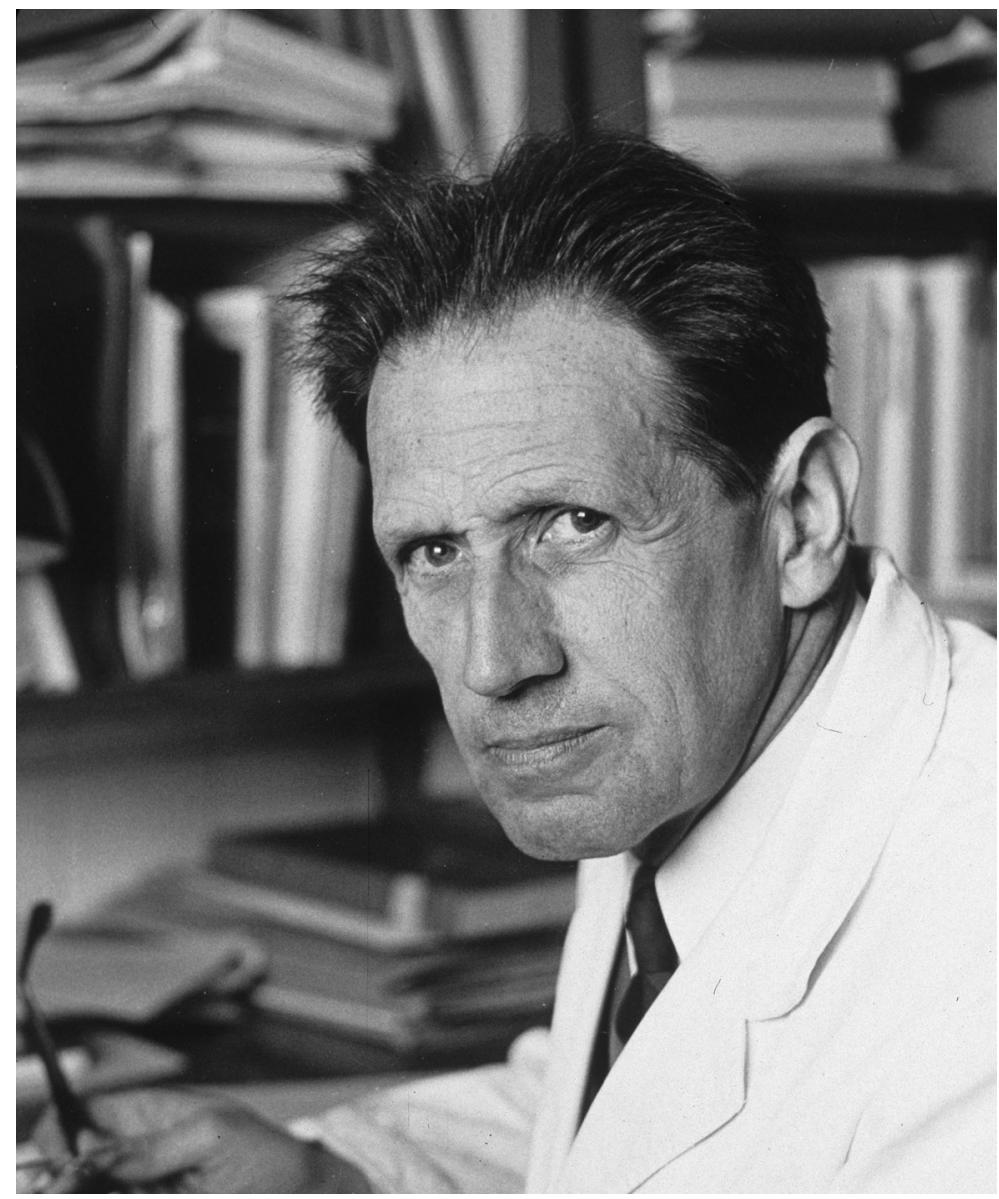

Margalef's father moved from an impoverished countryside to the city seeking better chances in life. Ramon was born in Barcelona on May 16, 1919. Despite the move to the city, his father remained faithful to his roots, keeping a piece of land with a vegetable garden where Ramon and his sister Vicenta received their first lessons in nature.
Margalef had many friends but his best one was undoubtedly Jose Maria Marcé, who studied business with him and shared his fondness for nature. They often left school to visit natural environments close to the city that were still relatively unspoilt. They collected empty aspirin tubes to take samples of plants and animals from ponds and reservoirs, and would spend hours 
trying to study them. As Margalef had no money to buy a microscope, he built one from bits and pieces that he bought from the Barcelona flea market, showing an extraordinary manual skill and a sound knowledge of optics at an early age.

Though Margalef dutifully pursued the studies that his father had laid down for him, his mind was elsewhere. In an attempt to restore his enthusiasm, his father hired a tutor, Alexandre Jacki, who taught him German, French and mathematics. Margalef considered Jacki to be the only real teacher he had and, what's more, Jacki allowed him to consult his Espasa Encyclopedia. For Margalef this was like having a window into unknown worlds.

The Spanish Civil War (1936-1939) left a permanent mark on Margalef. He and Marcé were drafted at the age of 19 and had the misfortune to take part in the Battle of the Ebro. Margalef lost track of his friend there and would never find out what had happened to him. On the rare occasions when he talked about Marcé his memories were remarkably detailed, as though they had been separated only a few hours instead of 60 years. At the end of the war, during a movement of troops to Barcelona, he escaped from the lorry that was transporting him. Shortly after the war he was drafted by the victorious Franco regime and was assigned to tasks such as loading and unloading rail cars and lorries. After many trials and tribulations, he was legally discharged.

After the formidable experience of the war, which he said matured him greatly, Margalef went to work in an insurance company. However, he adopted the firm belief that life was not worth living if one could not do something fulfilling. He soon felt the need to return to his vocation for the natural sciences He began to associate with people who were aware of his intelligence and diligence and advised him on how to channel his efforts. One of the contacts he made at this time was Karl Faust, who had a botanical garden in Blanes and paid for some of Margalef's journeys abroad. Putting his knowledge of foreign languages to the test, Margalef began to associate enthusiastically with scientists from France, Italy and England, sharing friendship and ideas. At this time his scientific interest focused on freshwater organisms and limnology in general.

The Institute of Applied Biology (Instituto de Biología Aplicada, IBA) directed by Dr. Francisco García del Cid gave him a scholarship in 1944. Though it was less than he earned in the insurance company, this scholarship allowed him to give up his job and concentrate on his education. In two years he finished secondary school, which normally took seven years at that time, and started a degree in Natural Sciences at the University of Barcelona. He was far older than his classmates and, to the displeasure of some of his lecturers, his attendance was irregular. While studying he also did research. In 1948 he spent a season at the Stazione Zoologica in Naples and participated in the International Limnology Congress in Zurich. Because

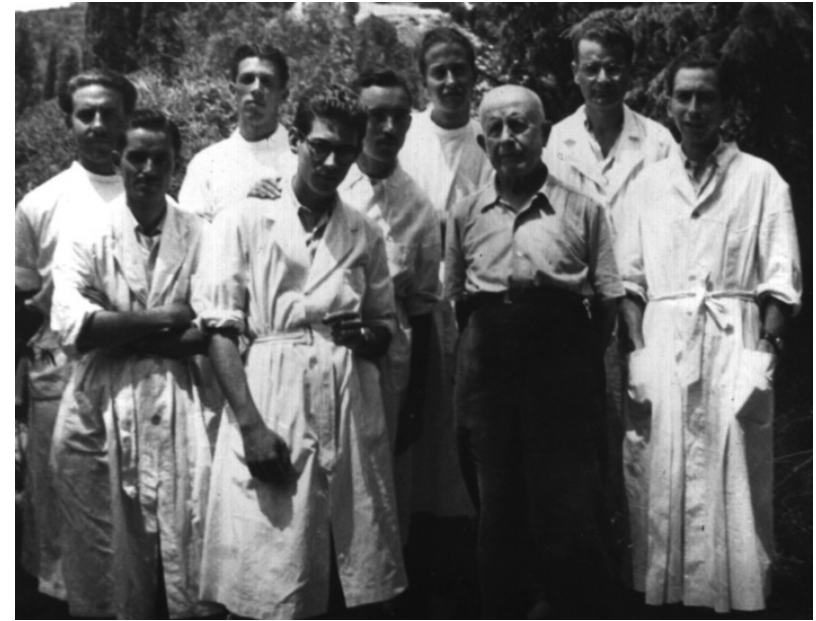

Some participants of the course "Introduction to Fisheries Research" at the "Mar i Murtra" Botanical garden in Blanes (summer 1949). From left to right: Pedro Arté, Buenaventura Andreu, Ramon Margalef, Miquel Durán, Manuel Gómez-Larrañeta, Miquel Massutí, Karl Faust, Julio Rodríguez-Roda, Josep M. Camps.

of his age, the academic authorities allowed him to skip a year, which led him to meet his future wife, Maria Mir, also studying at the University of Barcelona. He graduated in 1949 with a special mention.

In 1951, the Spanish National Research Council (Consejo Superior de Investigaciones Científicas, CSIC) set up the Fisheries Research Institute (Instituto de Investigaciones Pesqueras, IIP) to foster the growing interest in fisheries research in Spain, and appointed García del Cid as its director. This was a big step forward for Spanish oceanography and García del Cid relied heavily on Margalef's scientific judgement. After a few years the headquarters of the IIP in Barcelona and several coastal laboratories across Spain improved their facilities for experimentation, but something essential was missing: a ship for work at sea. At this time Margalef was known in the international oceanographic community and received invitations from several foreign institutions to take part in oceanographic missions with their ships. His generosity allowed other members of the IIP to participate in oceanographic cruises in other countries. Presenting themselves as colleagues of Margalef opened many doors when they visited coastal laboratories in France and Italy. Very soon young biologists were coming to Barcelona from all over the world to train with Margalef. Indeed, he was the soul of our IIP. If a problem arose in an experiment or in interpreting results, whether or not it was in his speciality, people consulted Margalef because they knew that his comments would make a decisive contribution to the research.

Margalef received grants to travel to the United States, where he obtained first-hand knowledge of its scientific community. He had job offers to stay in the USA and was very tempted to accept them, but a very important factor in his life prevented him from realizing this dream. His beloved wife Maria was from Mal- 


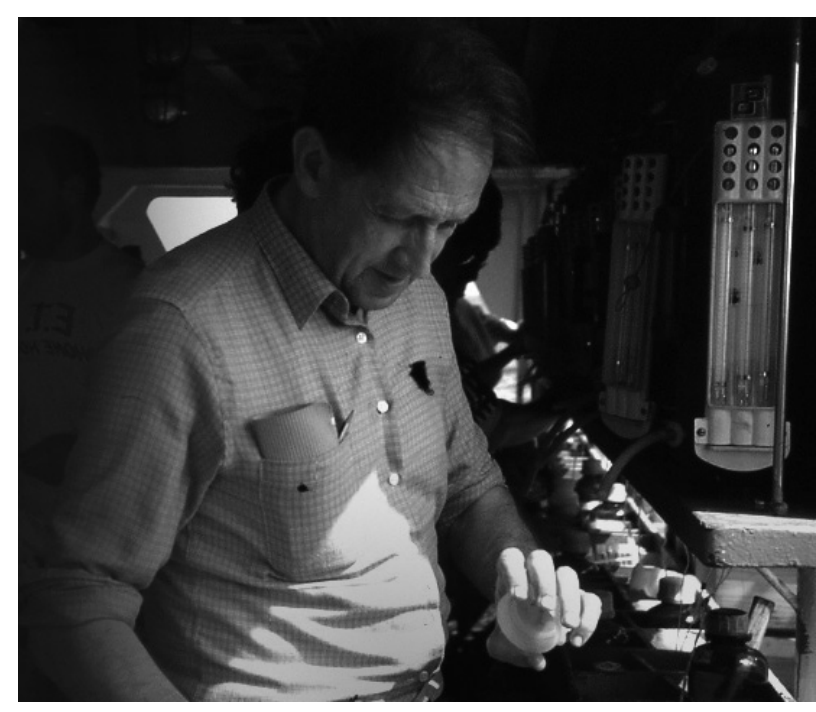

Ramon Margalef durig his last research cruise aboard the R/V García el Cid in the Mediterranean in 1999.

lorca and, like any good islander, she did not want to be far from her home town. In Latin America he had many contacts, starting with Venezuela. He also established links with an oceanographic laboratory on Isla Margarita and this "bridge" was operative for many years. The plankton samples collected in the Caribbean were fixed and sent to Barcelona to be studied by Margalef.

In October 1965, García del Cid was run over and killed just outside the university. All eyes turned towards Margalef to become the new director, but he was far from being attracted by the type of work it entailed. Nevertheless, he finally agreed in response to pressure from all his colleagues and from the Juan de la Cierva Board, which was directly responsible for the funding of the Institute. He held the post of director for only two years. In 1967, either because he was tired of the paperwork or because he wanted to create a school, Margalef applied for the post of professor of Ecology at the University of Barcelona, the first of its kind in Spain. His fame and prestige were such that, when the list of candidates was published, all the others withdrew. Until 1974 Margalef combined his professorship with oceanographic research at the IIP, but a time came when he was forced to choose. He decided to give priority to the University, but after 24 years at the Institute he did not abandon his roots, and above all the colleagues with whom he had shared experiences, work and friendship.

Margalef stayed at the University of Barcelona until his official retirement in 1994. There he promoted freshwater and terrestrial ecology as well as oceanography with a host of students, postdocs and collaborators who later populated universities and research institutes in Spain and beyond. He also developed a large body of knowledge in theoretical ecology based on years of continuous observation of nature, a sound understanding of mathematics and his highly intuitive ability to relate ideas from a diversity of fields. He continued to travel as much as he could, always seeking to learn from others and exchange ideas with colleagues all over the world. After his retirement he kept going to his office regularly, often visited the Institute of Marine Sciences (formerly the IIP), and stayed active writing papers. He passed away on May 23, 2004.

Throughout his life his great manual skills, driven by a constant proliferation of ideas, led him to make ingenious machines for laboratory experiments that highlighted facets of ecosystem functioning. One of the machines consisted of a vertical tube reproducing an ocean water column with phytoplankton populations that he kept carefully in an environmental chamber with artificial lighting. The waves on the water at the top of the tube were created by an eccentric wheel driven by an electric motor. This device, built with Meccano pieces, imitated the turbulence in the water column and allowed him to study the role played by the different nutrients. Working manually with such devices representing functional aspects of ecosystems led Margalef to think that, like Meccano, an ecosystem needs various elements performing different functions and working towards a common goal. No mechanical devices can be constructed with identical parts, just as no ecosystems have an equal representation of all species.

When studying a natural system Margalef took into account not only the individuals of different species but also the relationship between them and their relationship with the physical environment in space and time. The result was a puzzle in which each piece, however slight, played a decisive role in the functioning of the ecosystem. Margalef persistently strove to discover general regularities supported by principles that explained the functioning of a system and ultimately improved our understanding of the biosphere.

The ideas that Margalef contributed to the study of nature include principal component analysis applied to phytoplankton populations, the application of the principles of thermodynamics to the study of the ecosystem, the discovery that it is impossible to separate evolutionary processes in the concept of succession, the application of information theory to ecology in order to quantify the degree of organization of the ecosystem, the self-organizing capacity of ecosystems, the importance of exosomatic energy in the structure and dynamics of natural communities, and many more.

Nature is complex and Margalef wanted to show it in all its complexity. His mastery of many different scientific disciplines allowed him to synthesize ideas to reach high-level conclusions. He is generally considered as a scientist linked to the world of ecology but in fact his profound and inclusive thinking transcended into the humanities. Margalef's works, with over 400 articles and a dozen books, are his great legacy. His list of awards is endless, but one in particular stands out. In 1980 he received the Huntsman Award for Excellence in Marine Science from the Bedford Institute of Oceanography in Halifax. This is an award reserved 
for outstanding contributions to marine science and is considered the Nobel Prize in oceanography.

The biography of Ramon Margalef might suggest that he was fully aware of his worth and somewhat distant from those close to him. This was not the case. He was a straightforward, friendly, humble and modest person who hated praise and did not like to be the subject of conversation. He was a man of great patience, but reacted strongly to stupidity and frivolity. Those of us who were lucky enough to be his colleagues and friends can feel proud to have known one of the most outstanding individuals in our society.

\section{DIRECTORSHIP (1965-1967)}

Margalef was director of the Fisheries Research Institute (IIP) for only two years (1965-67). Although it is known that García del Cid, the former director of the IIP, had relied on Margalef's scientific vision for the management of the IIP since the early days, Margalef had been successful in avoiding direct management responsibilities and focusing on research. During his directorship, Margalef introduced a great revolution in the functioning of the Institute. He continued to do active research in his laboratory and, with the assistance of an administrative secretary, dealt with the paperwork by extending his already long working day. His obsession was the library, where he spent long hours and gently nudged the researchers towards reading articles that he thought would be stimulating for them. From the perspective of today, the most outstanding feature of this period in the life of the Institute was the progress made by the group, particularly at an international level, and the enthusiasm with which they worked despite the shortage of funding.

It was very common for different groups of researchers in an institute to have no open communication with their peers. Margalef quickly put an end to this situation. At a scientific meeting held every Thursday, the researchers explained their research, the objectives to be achieved and the problems they had encountered. Discussion and cooperation were inevitable.

The most intractable problem for Margalef was the relationship with the authorities of the CSIC and the Juan de la Cierva Board. At that time, the top man- agement posts were occupied by politicians and senior officers of the armed forces, who obviously acted very differently from scientists. This of course exasperated Margalef. Each trip to Madrid involved a dedication of energy that was not compensated by the negligible benefits that he felt he was obtaining. Nevertheless, Margalef, together with others, was instrumental in convincing the Spanish authorities to construct the first modern research vessel in Spain. The R/V Cornide de Saavedra became a reality a few years later, in 1972, with inaugural cruises led by Carles Bas and Margalef himself.

After his appointment, one day Margalef was walking in front of Dr. Carles Bas's office when Bas asked what the matter was. Margalef said: "Listen: fisheries studies in Barcelona have come to a standstill and you should have something to say about it". In surprise, Bas asked "So you've become interested in fisheries?" and Margalef answered, "I'm the director of the Fisheries Research Institute now". One week later Bas had produced a strategic document on the fisheries research to be carried out, and the department of natural resources was established. This line of research populated with followers of Bas is still going strong today. The anecdote shows that even if Margalef preferred to devote his time to research rather than management, he had a great sense of duty and extraordinary vision that led him to take the decisions that he thought were needed.

In 1967 Margalef occupied a post at the University of Barcelona, the first Ecology chair in Spain, but he kept doing oceanography research directly and with many students and colleagues from the IIP laboratories.

\section{BIBLIOGRAPHY}

Bas, C. Conversation on Mar 19, 2012.

Bonnín P. 1994. Ramon Margalef. Fundació Catalana per a la Recerca, Barcelona, $184 \mathrm{pp}$.

García del Cid F. 1957. Discurso de Contestación. Memorias de la Real Academia de Ciencias y Artes de Barcelona 32: 437-449.

Margalef R. Notes autobiogràfiques de Ramon Margalef López. 36 pp. Unpublished.

Peters F. 2010. Ramon Margalef, the curiosity driven life of a selftaught naturalist. American Society of Limnology and Oceanography. $66 \mathrm{pp}$.

Biography series ed.: F. Peters. 